\title{
Calmodulin-binding proteins in bovine semen
}

\author{
P. Manjunath, L. Chandonnet, L. Baillargeon and K. D. Roberts \\ Departments of Medicine and of Biochemistry, University of Montreal and the Endocrine Laboratory, \\ Maisonneuve-Rosemont Hospital Research Center, 5415 L'Assomption, Montreal, Quebec,
}

Canada, H1T $2 \mathrm{M} 4$

\begin{abstract}
An ${ }^{125}$ I-labelled calmodulin gel overlay procedure was used to direct calmodulin-binding proteins in bovine spermatozoa and seminal plasma. Several calmodulin-binding proteins with molecular masses ranging from 12 to $>200 \mathrm{kDa}$ were detected in epididymal and ejaculated spermatozoa. Certain of these proteins exhibited preferential calmodulin-binding in the presence of $\mathrm{Ca}^{2+}$, while others exhibited binding only in its absence. In seminal plasma, only two major proteins with molecular masses of 15 and $16 \mathrm{kDa}$ showed a higher calmodulin-binding activity in the presence of $\mathrm{Ca}^{2+}$, whereas several polypeptides in the range of $6-17 \mathrm{kDa}$ bound higher amounts of radiolabelled calmodulin in the absence of $\mathrm{Ca}^{2+}$. Our previous study has shown that a group of closely related major proteins, designated as BSP-A1, BSP-A2, BSP-A 3 and BSP-30 kDa, isolated from bovine seminal plasma (BSP) have molecular masses in the range of $15-30 \mathrm{kDa}$. This prompted us to investigate whether these polypeptides from bovine seminal fluid interact with calmodulin. The results indicated that calmodulin binds to purified BSP-A1, - A2, $-\mathrm{A} 3$ and BSP-30 kDa proteins in the presence and absence of $\mathrm{Ca}^{2+}$. Furthermore, many polypeptides of low molecular mass $(6-14 \mathrm{kDa}$ ) in bovine seminal plama that crossreact with these BSP proteins also show high calmodulinbinding activity, particularly in the absence of calcium. This was further demonstrated following the limited proteolysis of the BSP proteins. Several tryptic-peptides of BSP-A1/-A2 and BSP-30 kDa exhibited higher calmodulin-binding activity than the intact BSP proteins. In view of the key role of $\mathrm{Ca}^{2+}$ in triggering the acrosome reaction and the role of calmodulin in intracellular transport of calcium, it is suggested that BSP proteins are involved in sperm capacitation and the acrosome reaction.
\end{abstract}

\section{Introduction}

Calmodulin is an acidic protein of low molecular mass known for its ability to regulate many cellular processes in a calciumdependent manner (for review, see Cheung, 1980; Means et al., 1982). The presence of calmodulin has been demonstrated in spermatozoa isolated from a wide range of animals, including guinea-pig (Jones et al., 1980), boar (Camatini et al., 1986), bull (Feinberg et al., 1981; Weinman et al., 1986), hamster (Moore and Dedman, 1984) and rabbit (Jones et al., 1980; Camatini $e$ t al., 1991). Calmodulin constitutes about $0.1 \%$ of the total proteins in the sperm plasma membrane fraction in bovine species (Noland et al., 1985). The distribution of calmodulin in sperm cells has been determined by immunofluorescence and, according to these reports, calmodulin is localized in the acrosomal, the postacrosomal and equatorial regions as well as at the neck and tip of the flagellum. This localization of calmodulin in the acrosomal region together with data showing the calcium dependence of the acrosome reaction has supported the hypothesis that calmodulin is involved in this exocytotic process (Jones et al., 1980). Moreover, several calmodulin-binding proteins have been detected in hamster (Moore and Dedman,

Received 2 January 1992.
1984), bull (Olson et al., 1985) and boar (Peterson et al., 1989) spermatozoa and it has been suggested that the regulation of calmodulin is mediated through its interaction with binding proteins. Leclerc et al. $(1989,1990)$ showed that ejaculated cryopreserved bull spermatozoa contain three major calmodulinbinding proteins with molecular masses of 28,30 and $49 \mathrm{kDa}$. Heparin induced a decrease in the binding of these proteins to calmodulin and this finding was positively correlated to the fertilization rate. On the basis of these results, the authors suggest that sperm capacitation is associated with a decrease in the binding of calmodulin to sperm proteins of 28,30 and $49 \mathrm{kDa}$. One of the approaches to gain further insight into elucidating the function of calmodulin in capacitation and the acrosome reaction is therefore to identify the calmodulinbinding proteins that are present in spermatozoa and seminal plasma.

In this study, using a gel overlay technique, we investigated calmodulin-binding proteins of epididymal and ejaculated bovine spermatozoa as well as seminal fluid. We have established that a previously well-characterized family of proteins of bull seminal plasma (BSP) designated as BSP-A1, BSP-A2, BSP-A3 and BSP-30 kDa (collectively called BSP proteins; Manjunath and Sairam, 1987; Manjunath et al., 1987) and their tryptic fragments interact with calmodulin. Our previous 
studies have shown that these BSP proteins interact with highdensity lipoprotein, phospholipids and heparin (Manjunath et al., 1988, 1989; Chandonnet et al., 1990; Desnoyers and Manjunath, 1992). In view of the binding properties exhibited by these BSP proteins, we have suggested that they play a role in sperm capacitation (Manjunath et al., 1989; Chandonnet et al., 1990; Desnoyers and Manjunath, 1992). The present study, which demonstrates that BSP proteins also interact with calmodulin, further substantiates this hypothesis. Preliminary results of these studies have recently been presented (Chandonnet et al., 1989).

\section{Materials and Methods}

\section{Materials}

Phosphodiesterase $3^{\prime}, 5^{\prime}$-cyclic nucleotide activator (calmodulin) from bovine brain was purchased from Sigma (St Louis, MO). Affinity-pure goat anti-rabbit $\operatorname{IgG}(\mathrm{H}$ and $\mathrm{L}$ ) was obtained from Jackson Immuno-research Laboratories Inc. (Avondale, PA). $\mathrm{Na}^{125}$ I was obtained from Amersham (Oakville, Ontario). Trypsin from bovine pancreas was purchased from Boehringer Mannheim (Germany). Acrylamide, bisacrylamide, sodium dodecyl sulfate (SDS) and other electrophoresis products were obtained from Bio-Rad (Richmond, CA). Molecular mass markers of 14 to $94 \mathrm{kDa}$ were purchased from Pharmacia (Canada). Nitrocellulose paper was purchased from Schleicher and Schull (Germany). All other chemicals used were of analytical grade and obtained from commercial suppliers unless otherwise indicated. BSP-A1, $-\mathrm{A} 2,-\mathrm{A} 3$ and $-30 \mathrm{kDa}$ proteins were isolated by gelatin-agarose affinity chromatography as described previously (Manjunath et al., 1987). BSP-A1 and -A2 have an identical amino acid composition, but differ in their carbohydrate content. In this study, these proteins will be considered as a single chemical unit and will be referred to as BSP-A1/-A2.

\section{Sperm preparation}

Cauda epididymides with attached vasa deferentia were obtained from freshly killed bulls at a local slaughterhouse. The needle of a syringe was filled with light mineral oil and inserted into the lumen of the vas deferens and the light mineral oil was perfused retrograde into the epididymis. The epididymal tubule was then cut in one region and cells released were collected and washed three times $\left(600 \mathrm{~g}, 20^{\circ} \mathrm{C}, 5 \mathrm{~min}\right)$ in phosphate-buffered saline $\left(50 \mathrm{mmol}\right.$ sodium phosphate $1^{-1}, \mathrm{pH} 7.4$ containing $0.9 \%$ $\mathrm{NaCl}$. Spermatozoa were then routinely resuspended to give $40 \times 10^{6}$ cells $\mathrm{ml}^{-1}$, distributed in Eppendorf tubes in $1 \mathrm{ml}$ fractions and pelleted. Proteins in the sperm pellet were then solubilized in the sample buffer as described by Laemmli (1970).

Semen from four bulls was donated by the Centre d'Insémination Artificielle du Québec (CIAQ Inc., St-Hyacinthe, Québec, Canada). The ejaculated spermatozoa were prepared as described above.

\section{Iodination procedure}

Affinity-pure goat anti-rabbit IgG and bovine brain calmodulin were iodinated with ${ }^{125} \mathrm{I}$ using the lactoperoxidase method as described earlier (Manjunath and Sairam, 1982). Free iodine was removed by passing the reaction mixture through a Sephadex G-25 column equilibrated with phosphate-buffered saline containing $0.1 \%$ bovine serum albumin. The respective specific activities were usually between $60-80 \mu \mathrm{Ci} \mu^{-1}$ and $10 \mu \mathrm{Ci}$ $\mu \mathrm{g}^{-1}$

\section{Calmodulin gel overlay procedure}

Samples of proteins $(5-30 \mu \mathrm{g})$ were separated electrophoretically on a $15 \%$ polyacrylamide gel (Laemmli, 1970). The calmodulin-binding proteins were detected using slight modifications of the procedure of Glenney and Weber (1983). After electrophoresis, the proteins in the gel matrix were fixed in a solvent mixture (methanol:acetic acid:water; 40:10:50) for $1 \mathrm{~h}$ and SDS in the gels was removed by overnight incubation in $10 \%$ ethanol. The gels were then saturated in the overlay solution $10.5 \%$ bovine serum albumin, $0.02 \mathrm{~mol}$ imidazole $\mathrm{l}^{-1}$, $0.1 \mathrm{~mol} \mathrm{KCl} \mathrm{l}^{-1}$ and $0.02 \% \mathrm{NaN}_{3}, \mathrm{pH} \mathrm{7.0)}$ ) for $3 \mathrm{~h}$. The gels were then incubated for $16 \mathrm{~h}$ with $100 \mathrm{ml}$ of overlay solution containing ${ }^{125}$ I-labelled calmodulin $\left(2 \times 10^{6}\right.$ c.p.m. $)$. These incubations contained either $1 \mathrm{mmol} \mathrm{CaCl}_{2} \mathrm{l}^{-1}$ or $1 \mathrm{mmol}$ EGTA $1^{-1}$ and were performed at room temperature with gentle agitation. After incubation with ${ }^{125}$ I-labelled calmodulin, the gels were washed for 1-2 days in five changes of overlay solution containing $1 \mathrm{mmol} \mathrm{CaCl}_{2} \mathrm{l}^{-1}$ or $1 \mathrm{mmol}$ EGTA $\mathrm{l}^{-1}$. The gels were then dried and exposed for $10-70 \mathrm{~h}$ at $-80^{\circ} \mathrm{C}$ to Fuji X-Ray film.

\section{Electrophoresis and immunoblotting}

BSP proteins or alcohol precipitates of bovine seminal plasma $(10 \mu \mathrm{g})$ were separated electrophoretically on a $15 \%$ polyacrylamide gel according to Laemmli (1970). Separated proteins were transblotted onto nitrocellulose paper as described by Towbin et al. (1979). Nonspecific binding sites were blocked by incubating nitrocellulose papers in phosphate-buffered saline containing $0.05 \%$ Tween- 20 and $0.1 \%$ bovine serum albumin. The sheets were then incubated with the respective purified antibodies to the BSP protein (Chandonnet et al., 1990). The immunoreaction was visualized using an ${ }^{125}$-labelled goat anti-rabbit $\operatorname{IgG}(\mathrm{H}$ and $\mathrm{L})\left(2 \times 10^{6}\right.$ c.p.m. per $\left.50 \mathrm{~cm}^{2}\right)$.

\section{Proteolysis of BSP proteins}

Samples of BSP proteins were dissolved in $0.05 \mathrm{~mol}$ ammonium bicarbonate $\mathrm{l}^{-1}$ solution containing $0.1 \mathrm{mmol} \mathrm{CaCl}_{2}$ $\mathrm{I}^{-1}$. Trypsin from bovine pancreas was dissolved in the same solution and added to the BSP proteins (enzyme:substrate ratio of $1: 100, \mathrm{w} / \mathrm{w})$. Samples were then incubated at $37^{\circ} \mathrm{C}$ and aliquots were withdrawn at different times $(10,30,60$ and $120 \mathrm{~min})$. Trypsin was inactivated by immediately boiling the samples for $10 \mathrm{~min}$. The samples were then lyophilized and analysed for their calmodulin-binding properties by the ${ }^{125}$ I-labelled calmodulin gel overlay technique as described above. 


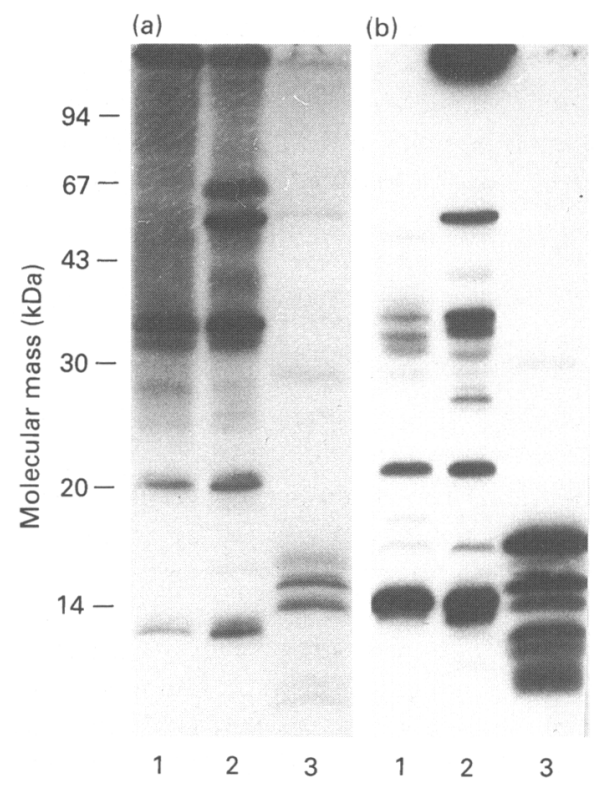

Fig. 1. Calmodulin-binding proteins in bovine spermatozoa and seminal plasma. Proteins extracted from $10 \times 10^{6}$ bull epididymal and ejaculated spermatozoa, and $30 \mu \mathrm{g}$ alcohol precipitates of seminal plasma were electrophoresed and subjected to the ${ }^{125}$ I-labelled calmodulin overlay procedure. Autoradiograms of calmodulin-binding

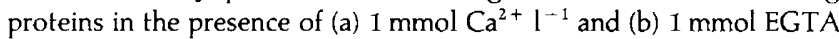
$\mathrm{I}^{-1}$. Lane 1 , proteins extracted from epididymal spermatozoa; lane 2 , proteins extracted from ejaculated spermatozoa; lane 3, alcohol precipitate of bovine seminal plasma. Molecular mass standards shown at the left are, from top to bottom, phosphorylase $b$, albumin, ovalbumin, carbonic anhydrase, trypsin inhibitor and $\alpha$-lactalbumin.

\section{Results}

\section{Calmodulin-binding proteins in bovine spermatozoa and seminal plasma}

The epididymal and ejaculated bull spermatozoa as well as the alcohol precipitates of bull seminal fluid contained many calmodulin-binding proteins as detected by the ${ }^{125}$ I-labelled calmodulin gel overlay technique. Certain of these proteins exhibited higher binding in the absence of calcium while others exhibited greater binding in the presence of this divalent cation.

The major calmodulin-binding proteins of epididymal spermatozoa had the following molecular masses: $>200,34$, 32,20 and $12 \mathrm{kDa}$ (Fig. Ia, lane I). The ejaculated spermatozoa contained all of these calmodulin-binding proteins and, in addition, they contained 57,49 and $40 \mathrm{kDa}$ calmodulin-binding proteins (Fig. 1a, lane 2). In contrast, seminal fluid contained two proteins ( 16 and $15 \mathrm{kDa}$ ) that bind high amounts of calmodulin and several other proteins ( 49 and $28 \mathrm{kDa}$ ) and many polypeptides with molecular masses between 6 and $17 \mathrm{kDa}$ that exhibit low calmodulin-binding activity (Fig. 1, lane 3).

The epididymal spermatozoa contained $45,34,32,28,20,18$, 16 and $12-14 \mathrm{kDa}$ proteins which bind calmodulin (Fig. 1b, lane 1). The major calmodulin-binding proteins of ejaculated spermatozoa had the following molecular masses: $>200,49$, $40,34,32,30,25,20,16$ and $12-14 \mathrm{kDa}$ (lane 2). Seminal fluid contained a $28 \mathrm{kDa}$ protein with weak binding activity and several polypeptides with molecular masses in the range of $6-17 \mathrm{kDa}$ that bind calmodulin (lane 3). Several of these polypeptides exhibit low calmodulin-binding activity in the presence of $\mathrm{Ca}^{2+}$, but higher binding in the absence of $\mathrm{Ca}^{2+}$, notably those with molecular masses of $20,18,16 \mathrm{kDa}$ and $12-$ $14 \mathrm{kDa}$ proteins in spermatozoa and the $6-17 \mathrm{kDa}$ polypeptides present in seminal fluid.

\section{Calmodulin-binding to BSP proteins}

We have shown earlier that the BSP proteins present in bovine seminal fluid have molecular masses in the ranges of $15-17 \mathrm{kDa}$ and $28-30 \mathrm{kDa}$. In view of the fact that several proteins from spermatozoa and seminal fluid with molecular masses $<30 \mathrm{kDa}$ bind ${ }^{125} \mathrm{I}$-labelled calmodulin (particularly in the absence of $\mathrm{Ca}^{2+}$ ) it was suspected that this group also contained BSP proteins. The possibility that the purified BSP proteins also bind to calmodulin was therefore investigated. Proteins BSP-A1/-A2, $\mathrm{A} 3$ and $-30 \mathrm{kDa}$ bind to calmodulin both in the presence and absence of $\mathrm{Ca}^{2+}$ (Fig. 2a, b), but the binding of calmodulin to these proteins was slightly higher in the absence of $\mathrm{Ca}^{2+}$. The lower band in lane 3 (Fig. 2a, b) with a molecular mass of $14 \mathrm{kDa}$ is a degradative product of the BSP$30 \mathrm{kDa}$ protein that was generated during storage. This band was not stained with Coomassie Blue (Fig. 2c, lane 3), but showed high calmodulin-binding activity, particularly in the absence of $\mathrm{Ca}^{2+}$. As indicated earlier, BSP-A1 and -A2 have the same primary sequence, but differ in their carbohydrate content. Usually they appear as closely migrating doublets (Fig. 2c, lane 1 ), but occasionally they migrate together as a single broad band as observed in the overlay experiment (Fig. 2a, b, lane 1).

\section{Immunoblotting}

Several polypeptides in the seminal fluid with molecular masses of $6-14 \mathrm{kDa}$ bind to calmodulin (Fig. 1) and, therefore, we suspected that some of these polypeptides may be derived from BSP proteins. Immunoblots were performed to establish this. Alcohol precipitates of bovine seminal fluid and authentic BSP proteins were separated by SDS-PAGE, transblotted onto nitrocellulose membranes and subjected to immunodetection with the purified antibodies against BSP proteins (Fig. 3). The immunoblot experiments showed the presence of polypeptides in the seminal fluid $(6-14 \mathrm{kDa})$ that crossreacted with anti-BSPA1/-A2 (Fig. 3 (a), lane 1), anti-BSP-A3 (Fig. 3 (b), lane 1) and anti-BSP-30 kDa (Fig. 3 (c), lane 1). This experiment, therefore, indicated that some of the polypeptides of seminal fluid with molecular masses of $6-14 \mathrm{kDa}$ are indeed derived from BSP proteins.

\section{Binding of calmodulin to tryptic peptides of BSP proteins}

Several polypeptides of bovine seminal fluid with molecular masses between 6 and $14 \mathrm{kDa}$ crossreact with antibodies against BSP proteins (Fig. 3). This indicates that some of these polypeptides are derived from the BSP proteins, possibly by proteolytic activity present in the seminal fluid. We, therefore, investigated whether tryptic-peptides of BSP proteins also bind to calmodulin. Samples of purified BSP-A1/-A2, -A3 and 
(a)

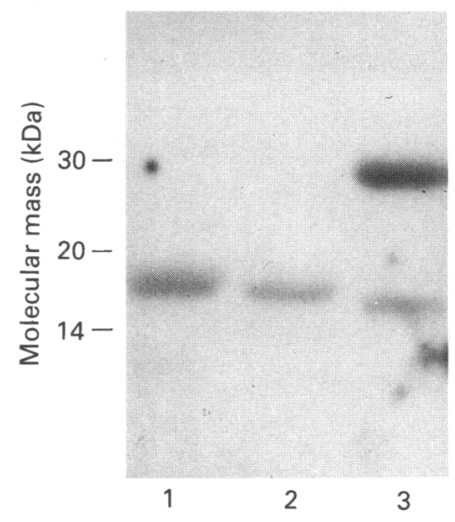

(b)

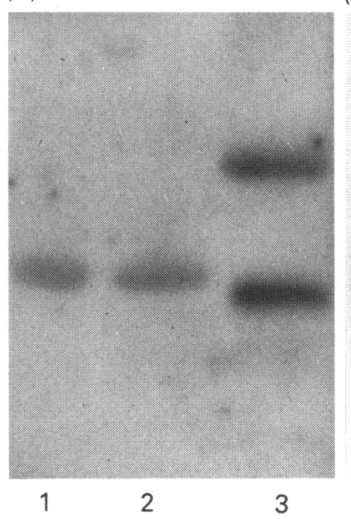

(c)

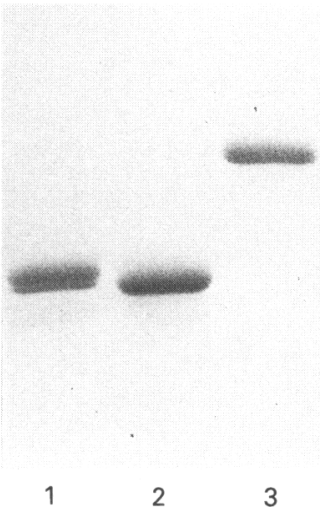

Fig. 2. Binding of ${ }^{125} \mathrm{I}$-labelled calmodulin to BSP-A1/-A2, BSP-A3 and BSP-30 kDa proteins. Approximately $10 \mu \mathrm{g}$ of purified bovine seminal plasma proteins were electrophoresed and subjected to the ${ }^{125} \mathrm{I}$-labelled calmodulin overlay procedure. Autoradiograms of calmodulin-binding

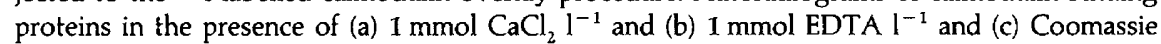
blue-stained gel of purified BSP proteins. Lane 1, BSP-A1/-A2; lane 2, BSP-A3; lane 3, BSP$30 \mathrm{kDa}$.

(a)

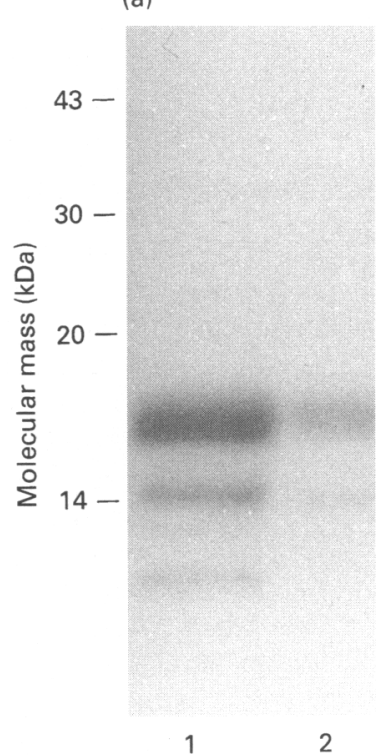

(b)

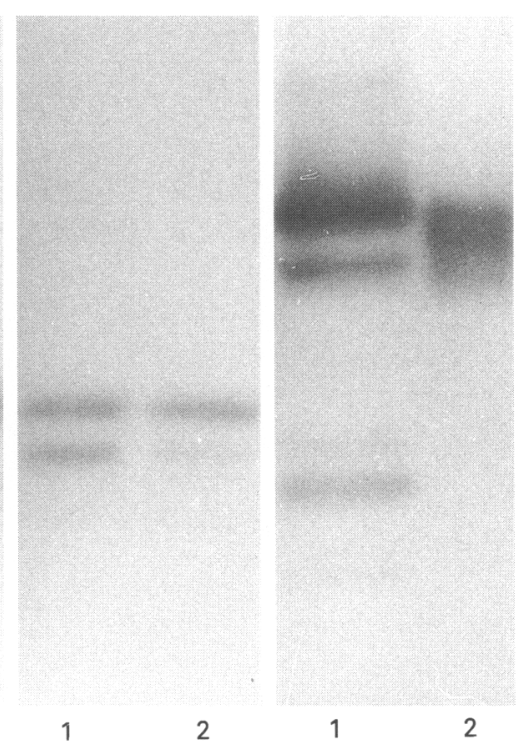

Fig. 3. Immunoblotting of seminal plasma proteins and purified bovine seminal plasma (BSP) proteins. Polypeptides were separated by SDSPAGE, transblotted to nitrocellulose and probed with (a) anti-BSP-A1/$A 2$, (b) anti-BSP-A3 and (c) anti-BSP-30 kDa. (a) Lane 1, alcohol precipitate of BSP; lane 2, authentic BSP-A1/-A2. (b) Lane 1, alcohol precipitate of bovine seminal plasma; lane 2, authentic BSP-A3. (c) Lane 1, alcohol precipitate of bovine seminal plasma; lane 2 , authentic $\mathrm{BSP}-30 \mathrm{kDa}$.

$-30 \mathrm{kDa}$ proteins were incubated separately with trypsin for different periods and the resulting tryptic peptides were analysed by the ${ }^{125}$ I-labelled calmodulin gel overlay procedure (Fig. 4). Tryptic peptides of BSP-A1/-A2 protein, which have molecular masses of $6-14 \mathrm{kDa}$, bound high amounts of calmodulin, in the presence or absence of $\mathrm{Ca}^{2+}$ (Fig. $4 \mathrm{a}, \mathrm{b}$, lanes $\mathrm{I}$ and 2). This binding was higher than that observed with native
BSP-A1/-A2 itself (Fig. 2a, b, lane 1). Similarly, tryptic peptides derived from BSP-30 kDa proteins also exhibited higher calmodulin-binding activity, particularly those polypeptides with molecular masses of 14 and 6-7 kDa (Fig. 4a, b, lanes 5 and 6). In contrast, the tryptic peptides of BSP-A3 exhibited no binding to calmodulin in the absence or presence of $\mathrm{Ca}^{2+}$ (Fig. $4 a, b$, lanes 3 and 4 , respectively). 
(a)

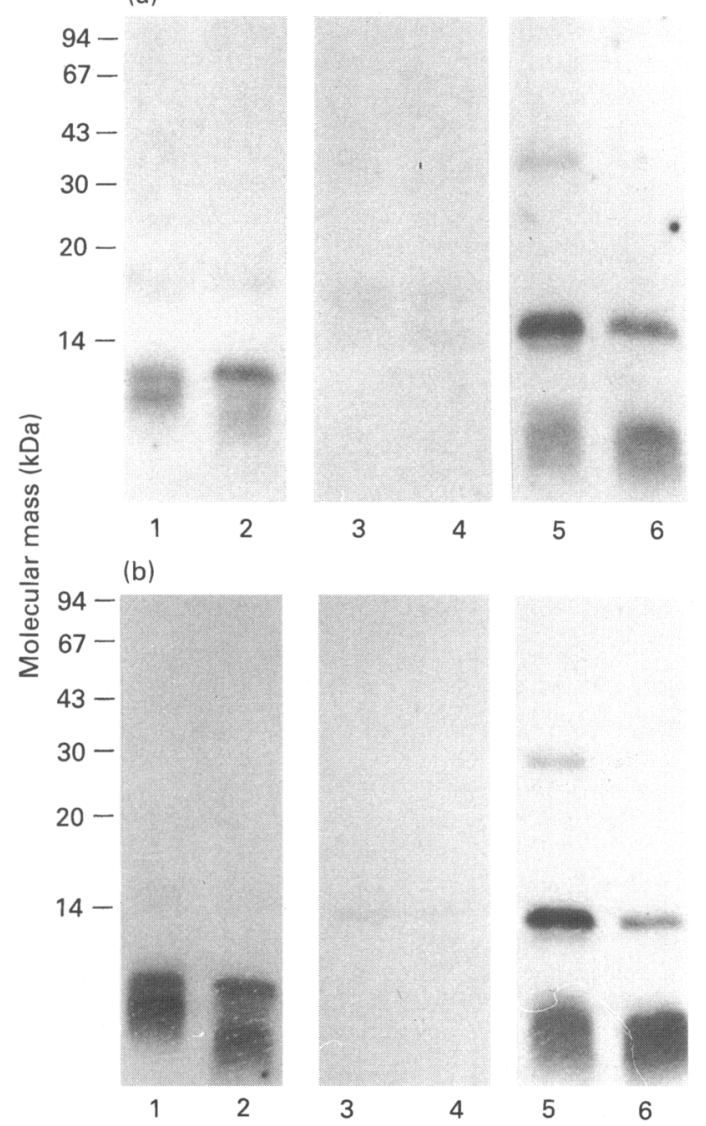

Fig. 4. Binding of ${ }^{125} \mathrm{I}$-labelled calmodulin to tryptic peptides of bovine seminal plasma (BSP) proteins. Approximately $10 \mu \mathrm{g}$ of tryptic peptides were electrophoresed and subjected to the ${ }^{125}$ I-labelled calmodulin overlay procedure. Autoradiograms of calmodulin-binding tryptic peptides in the presence of (a) $1 \mathrm{mmol} \mathrm{Ca}^{2+} \mathrm{l}^{-1}$ and (b) $1 \mathrm{mmol}$ EGTA $~^{-1}$. Lanes 1 and 2 correspond to 10 and 120 min tryptic digests of BSP-A1/-A2, respectively; lanes 3 and 4 correspond to 10 and $120 \mathrm{~min}$ tryptic digests of BSP-A3, respectively; lanes 5 and 6 correspond to 10 and 120 min tryptic digests of BSP-30 kDa protein, respectively.

\section{Discussion}

Ejaculated mammalian spermatozoa must undergo a series of physiological and morphological changes in the female reproductive tract to acquire the ability to fertilize the ovum. The first of these processes, capacitation, is characterized by removal or modification of certain surface components as well as an increase in the permeability of the plasma membrane to metal ions (Bedford, 1969; Yanagimachi and Usui, 1974). This influx of ions triggers the acrosome reaction, which is characterized by the fusion of the plasma membrane and outer acrosomal membrane (Bedford, 1968). It has been postulated that an influx of extracellular calcium ion $\left(\mathrm{Ca}^{2+}\right)$ is a prerequisite for mammalian spermatozoa to undergo the acrosome reaction (reviewed by Langlais and Roberts, 1985; Yanagimachi, 1988). Calmodulin has been reported to stimulate various calcium-dependent enzymatic activities through specific associations with calmodulin-binding proteins (Cheung, 1980; Means et al., 1982). It was therefore suggested that calmodulin might serve as a link between calcium influx and the acrosome reaction. Thus, the identification and characterization of the calmodulin-binding proteins present in spermatozoa and in seminal fluid should aid in the understanding of the role of calmodulin in sperm function as well as the mechanism of its regulation.

The gel overlay procedure used in this study indicates the presence of several calmodulin-binding proteins in bovine epididymal and ejaculated spermatozoa. However, there were marked differences in the patterns, particularly in molecular masses and the amount of radiolabelled calmodulin bound to these proteins. The differences observed are probably because ejaculated spermatozoa are exposed to fluids from the accessory glands. It is possible that some of the secretory products that bind to the ejaculated spermatozoa may also interact with calmodulin. Alternatively, proteolytic enzymes in the seminal plasma may hydrolyse those calmodulin-binding proteins that are present on the sperm surface and thereby change their molecular mass as well as their affinity for calmodulin. Our results also indicate a difference in calmodulin binding in the presence and absence of $\mathrm{Ca}^{2+}$; certain proteins bind calmodulin preferentially in the presence of $\mathrm{Ca}^{2+}$, whereas others bind calmodulin only in its absence. Increased binding of calmodulin in the absence of $\mathrm{Ca}^{2+}$ has also been observed with proteins in plasma membrane preparations (Noland et al, 1985) and outer acrosomal membrane complexes of bovine epididymal spermatozoa (Olson et al., 1985), and with proteins (21-14 kDa) of ejaculated boar spermatozoa (Camatini and Casale, 1987) and human spermatozoa (Aitken et al., 1988). The reason for this increased binding of calmodulin in the absence of $\mathrm{Ca}^{2+}$ is not clear, but it has been suggested that it may have some significance in the compartmentalization of calmodulin depending upon the $\mathrm{Ca}^{2+}$ concentration (Noland et al., 1985).

This study also revealed the presence of many calmodulinbinding proteins in bovine seminal plasma. A higher binding of calmodulin to these proteins was observed in the absence of $\mathrm{Ca}^{2+}$, particularly to those polypeptides with molecular masses $<16 \mathrm{kDa}$. Since our previous studies have shown that a group of major proteins (BSP-A1, - A2 and -A.3) of bovine seminal fluid have molecular masses in this range (Manjunath and Sairam, 1987), we investigated whether these proteins were calmodulin-binding proteins.

BSP-A1, - A2, - A.3 and - $30 \mathrm{kDa}$ proteins are secretory products of the seminal vesicles (Manjunath et al., 1987, 1988). The biochemical properties and structure of these proteins have been studied in detail (Manjunath, 1984; Kemme et al., 1986; Manjunath and Sairam, 1987; Manjunath et al., 1987, 1988; Seidah et al., 1987). We found, in the present study, that all BSP proteins bind calmodulin in the presence and absence of $\mathrm{Ca}^{2+}$. Interestingly, the proteolytic fragments of BSP-A1/-A2 and $-30 \mathrm{kDa}$ proteins exhibit higher calmodulin-binding activity than the native BSP proteins, particularly in the absence of $\mathrm{Ca}^{2+}$. One explanation for this higher binding could be that, in the native state, the calmodulin-binding site may be buried within the protein, rendering it inaccessible to calmodulin and, upon proteolysis, this site becomes more accessible.

The binding of calmodulin to BSP proteins and their proteolytic fragments may have some significance in sperm function. We have reported earlier that BSP proteins bind to the sperm surface after ejaculation (Manjunath et al., 1988). 
Recently, we identified the binding sites on spermatozoa to be choline phospholipids (Desnoyers and Manjunath, 1992). In view of these studies, it is possible that part of the sperm-bound BSP protein may be inserted into the plasma membrane to establish the communication with calmodulin, which is bound to the inner surface of the plasma membrane and thus participates in the regulation of events involving $\mathrm{Ca}^{2+}$ transport during capacitation and the acrosome reaction. Heparin or glycosaminoglycans which bind to BSP proteins may also participate in such a function. Glycosaminoglycans in oviductal and follicular fluids induce sperm capacitation or the acrosome reaction in several animals including bulls (reviewed in First and Parrish, 1987; Miller and Ax, 1990), but the mechanism by which heparin induces capacitation is not known. Using a ${ }^{125}$ I-labelled calmodulin gel overlay procedure, Leclerc et al. $(1989,1990)$ showed that ejaculated bovine spermatozoa contain specific calmodulin-binding proteins. Heparin induced a decrease in the binding of these proteins to calmodulin, which was positively correlated with the fertilization rate. In other studies, it has been reported that heparin induces $\mathrm{Ca}^{2+}$ uptake by sperm cells (Handrow et al., 1986). In view of these results, Leclerc et al. (1989) suggested that, during sperm capacitation, $\mathrm{Ca}^{2+}$ uptake could follow the decreased binding of calmodulin to the specific sperm proteins. Since BSP proteins also bind to heparin (Chandonnet et al., 1989), it is possible that this interaction could lead to decreased binding of calmodulin with the concomitant entry of $\mathrm{Ca}^{2+}$ into spermatozoa, thus initiating capacitation.

The present studies reveal that bovine spermatozoa and seminal fluid contain several calmodulin-binding proteins. Certain of these proteins bind calmodulin preferentially in the presence of $\mathrm{Ca}^{2+}$, while others exhibit higher binding in the absence of $\mathrm{Ca}^{2+}$. These studies also reveal that a family of closely related major proteins of bovine seminal plasma bind calmodulin. Limited proteolysis of these proteins enhanced this binding of calmodulin. The physiological significance of this increased binding remains to be determined. The interaction of BSP proteins with heparin shown in our previous studies (Chandonnet et al., 1990) as well as their binding to calmodulin suggest that the BSP proteins are probably involved in sperm capacitation.

This work was supported by grant MA10002 from the Medical Research Council of Canada. P. Manjunath is a recipient of a Senior Scholarship from the Fonds de la Recherche en Santé du Québec.

\section{References}

Aitken RJ, Clarkson JS, Hulme MJ and Henderson CJ (1988) Analysis of calmodulin acceptor proteins and the influence of calmodulin antagonists on human spermatozoa Gamete Research 21 93-III

Bedford JM (1968) Ultrastructural changes in the sperm head during fertilization in the rabbit American Journal of Anatomy 123 329-358

Bedford JM (1969) Morphological aspects of sperm capacitation in mammals Advances in Bioscience 4 35-50

Camatini M and Casale A (1987) Actin and calmodulin coexist in the equatorial segment of ejaculated boar sperm Gamete Research 17 97-105

Camatini M, Anelli G and Casale A (1986) Immunochemical localization of calmodulin in intact and acrosome-reacted boar sperm European Journal of $C_{e} l l$ Biology $4189-96$
Camatini M, Colombo A and Bonfanti P (1991) Identification of spectrin and calmodulin in rabbit spermiogenesis and spermatozoa Molecular Reproduction and Development 28 62-69

Chandonnet L, Roberts KD and Manjunath P (1989) Interaction d'une famille de protéines du plasma séminal bovin avec la calmoduline Médecine Sciences $\mathbf{5}$ (Supplement 3), 68A

Chandonnet L, Roberts KD, Chapdelaine A and Manjunath P (1990) Identification of heparin-binding proteins in bovine seminal plasma Molecular Reproduction and Development 26 313-318

Cheung WY (1980) Calmodulin plays a vital role in cellular regulation Science 207 19-27

Desnoyers L and Manjunath P (1992) Major proteins of bovine seminal plasma exhibit novel interactions with phospholipids Joumal of Biological Chemistry $26710149-10155$

Feinberg J, Weinmann J and Weinmann S (1981) Immunocytochemical and biochemical evidence for the presence of calmodulin in bull sperm flagellum Biochimica et Biophysica Acta 673 303-311

First NL and Parrish JJ (1987) In-vitro fertilization in ruminants Journal of Reproduction and Fertility Supplement 34 151-165

Glenney JR Jr and Weber K (1983) Detection of calmodulin-binding polypeptides separated in SDS-polyacrylamide gels by a sensitive [ $\left.{ }^{125} \mathrm{I}\right]$-calmodulin gel overlay assay Methods in Enzymology 102 204-210

Handrow RR, Parrish JJ and Susko-Parrish JL (1986) Effect of glycosaminoglycans on capacitation and the acrosome reaction of bovine and hamster sperm Biology of Reproduction Supplement 3493

Jones HP, Lenz RW, Palevitz BA and Cormier MJ (1980) Calmodulin localization in mammalian spermatozoa Proceedings of the National Academy of Sciences USA 77 2772-2776

Kemme M, Madiraju MVVS, Krauhs E, Zimmer M and Scheit KH (1986) The major protein of bull seminal plasma is a secretory product of seminal vesicle Biochimica et Biophysica Acta 884 282-290

Laemmli UK (1970) Cleavage of structural proteins during the assembly of the head of bacteriophage T4 Nature $227680-685$

Langlais J and Roberts KD (1985) A molecular membrane model of sperm capacitation and the acrosome reaction of mammalian spermatozoa Gamete Research 12 183-224

Leclerc P, Langlais J, Lambert RD, Sirard MA and Chafouleas JG (1989) Effect of heparin on the expression of calmodulin-binding proteins in bull spermatozoa Joumal of Reproduction and Fertility 85 615-622

Leclerc P, Sirard MA, Chafouleas JG and Lambert RD (1990) Decreased binding of calmodulin to bull sperm proteins during heparin-induced capacitation Biology of Reproduction 42 483-489

Manjunath P (1984) Gonadotropin release and stimulatory and inhibitory proteins in bull seminal plasma. In Gonadal Proteins and Peptides and their Biological Significance, pp 49-61 Eds MR Sairam and LE Atkinson. World Scientific Publishing Co., Singapore

Manjunath P and Sairam MR (1982) Biochemical, biological and immunological properties of chemically deglycosylated human choriogonadotropin Journal of Biological Chemistry 257 7109-7115

Manjunath P and Sairam MR (1987) Purification and biochemical characterization of three major acidic proteins (BSP-A1, BSP-A2 and BSP-A3) Biochemical Journal 241 685-692

Manjunath P. Sairam MR and Uma J (1987) Purification of four gelatin-binding proteins from bovine seminal plasma by affinity chromatography Bioscience Reports 7 231-237

Manjunath P, Baillargeon L, Marcel YL, Seidah NG, Chrétien M and Chapdelaine A (1988) Diversity of novel peptides and proteins of gonadal fluids. In Molecular Biology of Brain and Endocrine Systems pp 259-273 Eds KW McKerns and M Chrétien. Plenum Press, New York

Manjunath P, Marcel YL, Uma J, Seidah NG, Chrétien M and Chapdelaine A (1989) Apolipoprotein A-1 binds to a family of bovine seminal plasma proteins Joumal of Biological Chemistry $26416853-16857$

Means AR, Tash JS and Chafouleas JG (1982) Physiological implications of the presence, distribution and regulation of calmodulin in eukaryotic cells Physiological Reviews 62 1-38

Miller DJ and Ax RL (1990) Carbohydrates and fertilization in animals Molecular Reproduction and Development 26 184-198

Moore PB and Dedman JR (1984) Calmodulin, a calmodulin acceptor protein, and calcimedins: antibody localizations in hamster sperm Journal of Cellular Biochemistry 25 99-107

Noland TD, Van Eldik LJ, Garbers DL and Burgess WH (1985) Distribution of calmodulin and calmodulin-binding proteins in membranes from bovine epididymal spermatozoa Gamete Research 11 297-303 
Olson GE, Windfrey VP, Garbers DL and Noland TD (1985) Isolation and characterization of a macromolecular complex associated with the outer acrosomal membrane and bovine spermatozoa Biology of Reproduction 33 $761-779$

Peterson RN, Chaudhry P and Tibbs B (1989) Calcium-binding proteins of boar spermatozoan plasma membranes: identification and partial characterization Gamete Research 23 49-60

Seidah NG, Manjunath P, Rochemont J, Sairam MR and Chrétien M (1987) Complete amino acid sequence of BSP-A3 from bovine seminal plasma: homology to PDC-109 and to the collagen-binding domain of fibronectin Biochemical Joumal 243 195-203
Towbin H, Stehelin T and Gordon J (1979) Electrophoretic transfer of proteins from polyacrylamide gels to nitrocellulose sheets: procedure and some applications Proceedings of the National Academy of Sciences USA $\mathbf{7 6}$ 4350-4354

Weinman S, Ores-Carton C, Rainteau D and Puszkin S (1986) Immunoelectron microscopic localization of calmodulin and phospholipase $A_{2}$ in spermatozoa Joumal of Histochemistry and Cytochemistry 34 I171-1179

Yanagimachi R (1988) Mammalian fertilization. In The Physiology of Reproduction, pp 135-186 Eds E Knobil and J Neill. Raven Press, New York

Yanagimachi R and Usui N (1974) Calcium dependence of the acrosome reaction and activation of guinea pig spermatozoa Experimental Cell Research 89 161-174 